\title{
STUDI KELIMPAHAN BENIH LOBSTER (PANULIRUS SPp.) BERDASARKAN KARAKTERISTIK OSEANOGRAFI DI PERAIRAN DESA RANOOHA RAYA KECAMATAN MORAMO KABUPATEN KONAWE SELATAN
}

\author{
Study of Seed Lobster Abundance (Panulirus spp.) based on Oceanography \\ Characteristics in Ranooha Raya Seawaters of Moramo, South Konawe
}

\author{
Idul Fitriansyah ${ }^{1 *}$, Muhammad Ramli ${ }^{1}$, La Ode Alirman $\mathrm{Afu}^{2}$ \\ ${ }^{1}$ Program Studi Ilmu Kelautan, ${ }^{2}$ Program Studi Oseanografi, \\ Fakultas Perikanan dan Ilmu Kelautan, Universitas Halu Oleo. \\ Jl. H.E.A Mokodompit Kampus Hijau Bumi Tridharma Anduonohu Kendari 93232. \\ *E-mail: fitriansyahidu198@gmail.com
}

\begin{abstract}
Abstrak
Siklus hidup lobster terdiri dari beberapa stadia dan setiap stadia dipengaruhi oleh kondisi lingkungan. Lobster berukuran benih menyerupai lobster dewasa namun belum memiliki kulit luar keras dan belum mengandung zat kapur. Penelitian ini bertujuan untuk mengetahui kelimpahan benih lobster (Panulirus spp.) berdasarkan karakteristik oseanografi. Pengambilan data dilakukan pada bulan Oktober - Desember 2019 di Perairan Desa Ranooha Raya, Kecamatan Moramo, Kabupaten Konawe Selatan. Pengambilan data karakteristik oseanografi dilakukan secara in situ sedangkan pengumpulan data kelimpahan benih lobster menggunakan alat kolektor benih lobster yang dikenal dengan nama "pocong" pada tiga stasiun pengamatan dengan tiga kali ulangan. Suhu perairan berkisar 29-30 ${ }^{\circ} \mathrm{C}$, salinitas $29-34 \mathrm{ppt}$, kecerahan $58-93 \%$, kecepatan arus 0.08-0.09 m/det, pH 7-8 dan DO 5.3-5.73 mg/L. Karakteristik osenografi tersebut masih sesuai untuk kehidupan benih lobster. Jenis lobster yang tertangkap di lokasi penelitian adalah benih lobster mutiara (Panulirus ornatus) dan benih lobster pasir (Panulirus homarus). Kelimpahan benih lobster yang tertinggi pada lokasi penelitian untuk jenis lobster mutiara (Panulirus ornatus) mencapai $69.85 \%$ dan benih lobster pasir (Panulirus homarus) mencapai $44.58 \%$. Karakteristik oseanografi yang mempengaruhi kelimpahan benih lobster adalah suhu, salinitas, kecerahan, kecepatan arus, $\mathrm{pH}$ dan DO.
\end{abstract}

Kata Kunci: Benih lobster, kelimpahan, karakteristik oseanografi, Desa Ranooha Raya.

\begin{abstract}
The lobster life cycle consists of several stages and each stage is influenced by environmental conditions. Lobster seed is a post larval stage that resembles an adult without hard carapace and calcium. This study aimed to determine the abundance of lobster seeds (Panulirus spp.) based on oceanographic characteristics. Data was collected from October to December 2019 in Ranooha Raya, Moramo Sub District of South Konawe. In situ measurement was applied to determine the oceanographic characteristics while the seeds were collected using a lobster seed collector known as "pocong" at three stations with three replications. Water temperature ranged $29-30^{\circ} \mathrm{C}$, salinity ranged $29-34 \mathrm{ppt}$, brightness ranged 58 $93 \%$, current velocity ranged $0.08-0.09 \mathrm{~m} / \mathrm{sec}, \mathrm{pH}$ ranged 7-8 and DO ranged 5.3-5.73 mg/ L. These characteristics were still suitable for lobster seed life in location. There were two types of lobsters caught in the area i.e pearl lobster seeds (Panulirus ornatus) and sand lobster seeds (Panulirus homarus). The highest abundance of pearl lobster (Panulirus ornatus) and sand lobster seeds (Panulirus homarus) were $69.85 \%$ and $44.58 \%$ respectively. Oceanographic characteristics that affect lobster seed abundance were temperature, salinity, brightness, current velocity, $\mathrm{pH}$ and DO.
\end{abstract}

Keywords: Lobster seeds, abundance, oceanographic characteristics, Ranooha Raya Seawaters.

\section{Pendahuluan}

Udang karang atau lebih dikenal dengan lobster, terdiri dari dua kelompok besar, yaitu lobster berduri dan lobster bercapit. Perairan Indonesia di temukan 5 jenis lobster yang memiliki nilai ekonomis yang tinggi dan merupakan sumberdaya perairan yang dapat diperbaharui, dieksploitasi guna memenuhi kebutuhan komsumsi. Lobster laut sangat beragam jenisnya dan mempunyai spesifikasi perkembangan dan tabiat hidup berbeda.
Salah satu jenis lobster yang potensial adalah lobster mutiara, hidup di perairan IndoPasifik, daerah lintang rendah.

Lobster berukuran benih menyerupai lobster dewasa hanya belum mempunyai kulit luar yang keras dan mengandung zat kapur. Fase post larva (puerulus) mengalami pergantian kulit beberapa kali dan menjadi lobster muda/kecil dan telah memiliki kerangka luar yang keras dan berzat kapur serta tinggal di dasar perairan (Pratiwi, 2013). 
Menurut Musbir dkk., (2014), bahwa sejumlah benih lobster lebih sering jumpai berlindung pada area karang dan patahan karang dan pada pinggiran akar pohon mangrove untuk menghindar dari pemangsa dan penangkapan.

Lobster umumnya ditemukan pada lingkungan perairan terumbu karang, dari permukaan sampai pada kedalaman beberapa meter, terutama di perairan hangat dengan kisaran suhu $20-30^{\circ} \mathrm{C}$ dan biasanya mendiami tempat yang terlindungi, oleh batu. Lobster memijah pada kedalaman sekitar $10 \mathrm{~m}$ ketika oviposisi, telur-telur muncul dan melintasi spermatophora sehingga terjadifertilisasi. Telur dilengketkan pada pleopods, sebagai tempat kantong pengeraman.Pada $P$. interruptus, inkubasi selama 9-10 minggu, menetas menjadi larva stadia filosoma (Yusnaini et al., 2009).

Kelimpahan suatu organisme merupakan konsekuensi dari respon-respon spesies terhadap karakteristik oseanografi atau variasi lingkungan yang terjadi di alam dapat mempengaruhi kelimpahan dan habitat benih lobster, seperti suhu, kecepatan arus, salinitas, keasaman $\mathrm{pH}$, kecerahan dan kedalaman, pada perairan tersebut.

Perairan Desa Ranooha Raya merupakan psalah satu daerah penghasil benih lobster di Sulawesi Tenggara dan salah satu kawasan yang wilayah pesisirnya menjadi habitat bagi benih lobster (Panulirus spp.). Dimana di wilayah ini para nelayan sering melakukan penangkapan. Penangkapan benih lobster dilakukan dengan menggunakan alat tangkap pocong (Shelter) sebagai salah satu media perlindungan bagi benih lobster untuk bersembunyi dari predator yang dipasang di perairan. Penelitian ini bertujuan untuk mengetahui kelimpahan benih lobster (Panulirus spp.) berdasarkan karakteristik oseanografi.

\section{Bahan dan Metode}

Penelitian ini telah dilaksanakan pada bulan Februari - Agustus 2019 meliputi tahap persiapan, pengambilan data lapangan, pengelolaan data sampai pembuatan laporan penelitian. Pengambilan data dilaksanakan pada bulan Mei-Juli 2019 dan bertempat di Perairan Ronooha Raya Kecamatan Moramo Kabupaten Konawe Selatan, Provinsi Sulawesi Tenggara (Gambar 1).

Langkah awal sebelum melakukan penelitian yaitu dengan melakukan survey pendahuluan terlebih dahulu. Survei ini bertujuan untuk melihat kondisi awal lokasi penelitian dan informasi yang relevan dengan penelitian. Hasil dari survey ini yang dijadikan sebagai dasar untuk menentukan titik pengambilan data (stasiun penelitian).

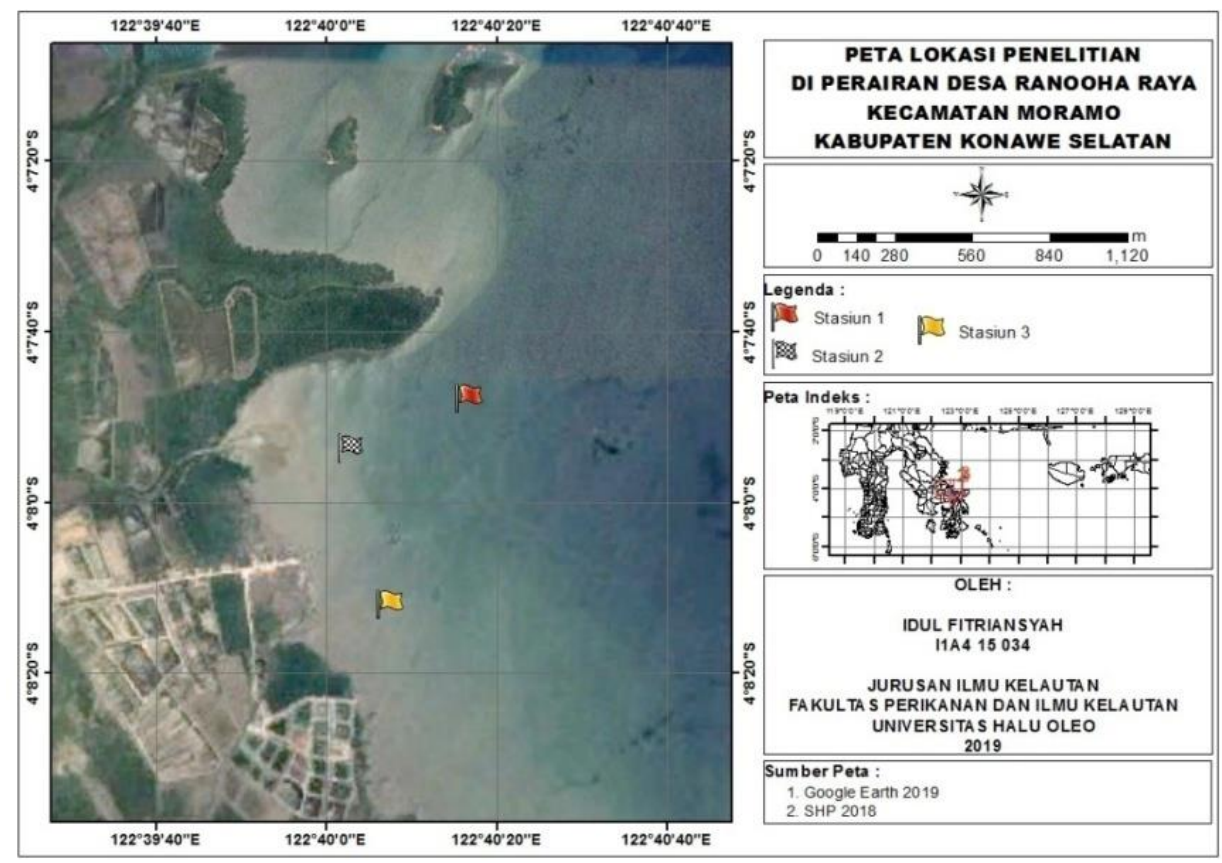

Gambar 1. Peta Lokasi Penelitian 
Tabel 1.Alat dan Bahan yang Digunakan

\begin{tabular}{|c|c|c|c|c|}
\hline No. & Alat dan Bahan & Satuan & Kegunaan & $\begin{array}{c}\text { Jumlah } \\
\text { Unit }\end{array}$ \\
\hline A. & Alat & & & \\
\hline 1 & Thermometer & ${ }^{\circ} \mathrm{C}$ & Mengukur Suhu Perairan & 1 \\
\hline 2 & Secchi disk & $\%$ & Mengukur Kecerahan & 1 \\
\hline 3 & Handrefractometer & ppt & Mengukur Salinitas Perairan & 1 \\
\hline 4 & $\mathrm{pH}$ indicator & - & Mengukur pH Perairan & 1 \\
\hline 5 & GPS & - & Mengambil Titik Koordinat & 1 \\
\hline 6 & Tongkat berskala & $\mathrm{m}$ & Kedalaman & 1 \\
\hline 7 & Layangan Arus & $\mathrm{m} /$ detik & Kecepatan Arus & 1 \\
\hline 8 & Alat Tulis & - & Menulis Hasil Penelitian & 4 \\
\hline 9 & Kamera & - & Dokumentasi Penelitian & 1 \\
\hline 10 & Aquades & $\mathrm{ml}$ & $\begin{array}{l}\text { Menetralkan } \\
\text { refraktometer }\end{array}$ & 4 \\
\hline 11 & Kapas & - & $\begin{array}{l}\text { Mensterilkan hand } \\
\text { refraktometer }\end{array}$ & 4 \\
\hline 12 & Botol sampel & $\mathrm{mg} / \mathrm{l}$ & Mengambil Sampel DO & 3 \\
\hline 13 & $\begin{array}{l}\text { Buku identifikasi } \\
\text { jenis lobster, WWF } \\
\text { Indonesia }(2015)\end{array}$ & - & $\begin{array}{l}\text { Mengidentifikasi Jenis } \\
\text { Lobster }\end{array}$ & 2 \\
\hline 14 & Jangka Sorong & $\mathrm{cm}$ & Mengukur sampel & 1 \\
\hline 15 & $\begin{array}{l}\text { Pocong (alat tangkap } \\
\text { benih lobster) } \\
\text { Alkohol }\end{array}$ & $\mathrm{m}$ & Mengambil sampel & 3 \\
\hline 16 & & $\%$ & Mengawetkan Sampel & 1 \\
\hline B. & Bahan & & & \\
\hline 1 & Lobster & Ind & Sampel Penelitian & 2 \\
\hline 2 & $\mathrm{MnSo}_{4}$ & $\mathrm{ml}$ & Pengikat DO & 1 \\
\hline 3 & Azida & $\mathrm{ml}$ & Pengikat DO & 1 \\
\hline
\end{tabular}

Penentuan titik stasiun penelitian menggunakan GPS Garmin 76CX untuk menandai lokasi penelitian yang diamati. Penentuan tiga titik stasiun yang dipilih dapat mewakili kelimpahan benih lobster berdasarkan karakteristik oseanografi di Desa Ranooha Raya . Stasiun I, terletak pada titik koordinat $04^{\circ} 7^{\prime} 53,68^{\prime \prime} \mathrm{LS}-122^{\circ} 40^{\prime} 16,70^{\prime \prime}$ BT dimana stasiun ini berhadapan dengan laut lepas. Stasiun II, terletak pada titik koordinat $04^{\circ} 8^{\prime} 1,52^{\prime \prime}$ LS - 122 $40^{\circ} 1,82^{\prime \prime}$ BT, terletak pada keluarnya air payau dari tambak masyarakat. Stasiun III, terletak pada titik koordinat $04^{\circ} 8^{\prime} 18,54^{\prime \prime} \mathrm{LS}-122^{\circ} 40^{\prime} 7,73^{\prime \prime} \mathrm{BT}$, stasiun ini berhadapan langsung dengan pemukiman masyarakat.

Pengamatan kelimpahan benih lobster, kondisi kualitas perairan, dan total hasil tangkapan di Desa Ranooha Raya. Pengumpulan data kelimpahan lobster pada setiap stasiun pengamatan dengan caramemasang alat kolektor benih lobster

yang dikenal dengan nama "pocong" pada tiga stasiun pengamatan.

Alat tangka pocong biasanya terbuat dari karung semen sehinggacara kerja alat pocongan dalam menangkap benih lobster sangat sederhana. Alat yang sudah jadi akan diikatkan di sepanjang keramba ikan milik nelayan di laut dan diturunkan beberapa meter hingga dekat terumbu karang. Pengumpulan data kelimpahan lobster pada setiap stasiun pengamatan dilakukan satu minggu dengan cara mengangkat kolektor dari dalam air untuk mengumpulkan benih lobster yang menempel di sela-sela pocong tersebut.

Adapun prosedur pengambilan data benih lobster terdiri atas beberapa tahap, yaitu:

\section{1) Tahap Persiapan Bahan dan Perakitan Alat}

Bahan yang disiapkan untuk membuat alat tangkap pocong yaitu terbuat dari waring, karung semen, tali nilon, patok, tasi, pemberat (batu) dan botol (pelampung), setelah bahan 
terkumpul kemudian dirakit sehingga menjadi alat tangkap pocong.

\section{2) Tahap Pemasangan Alat}

Bahan yang telah dirakit segera dibawa ke perairan untuk melakukan pemasangan. Pemasangan dilakukan dengan cara menancapkan patok ke dasar perairan, lalu alat tangkap pocong diikat dan digantungkan pada patok agar terbawa arus pada proses pemasangan. Pada setiap satu alat tangkap pocong memiliki panjang 50 meter dan terdapat 26 rumpon dengan jarak rumpon pertama dengan rumpon selajutnya $1,5 \mathrm{~m}$ dengan jumlah kipas-kipas 10 lembar dalam rumpon.

\section{3) Tahap Pengambilan Sampel Benih \\ Lobster}

Pengumpulan data kelimpahan lobster pada setiap stasiun pengamatan dilakukan pada bulan mei-juni dengan cara mengangkat kolektor dari dalam air untuk mengumpulkan benih lobster yang menempel di sela-sela pocong tersebut.

\section{4) Pengukuran Parameter Lingkungan di Lapangan}

Pengukuran parameter perairan dilakukan untuk mengetahui kondisi perairan tersebut. Pengukuran parameter perairan meliputi pengukuran parameter fisika yaitu suhu, kecerahan, kedalaman dan kecepatan arus serta pengukuran parameter kimia yaitu salinitas, $\mathrm{pH}$, dan DO. Untuk pengukuran parameter biologi yaitu benih lobster (Panulirus spp.).

Pengukuran suhu perairan dilakukan menggunakan Thermometer yaitu dengan mencelupkan thermometer ke dalam perairan pada kedalaman areal stasiun pengamatan.

Pengukuran salinitas perairan dilakukan langsung di lapangan dengan menggunakan handrefraktometer yaitu dengan diberikan 1-2 tetes air laut pada kacanya kemudian ditutup dan dapat dilihat angkaa yang terbaca pada skala.

Secchi disc diturunkan lebih dalam lagi sehingga benar-benar tidak Nampak, kemudian ditarik pelan-pelan hingga pertama kali nampak, ditandai tali secchi disc dengan karet gelang dan diukur panjang tali lalu dicatat.
$\mathrm{D}=\frac{\mathrm{D} 1+\mathrm{D} 2}{2}$

$\mathrm{D} 1=$ Secchi disc pertama kali tidak nampak

D2 = Secchi disc pertama kali nampak

Pengukuran kedalaman dilakukan dengan menggunakan patok berskala yang ditancapkan ke dasar perairan kemudian dilihat batas air patok tersebut. Pengukuran ke dalaman ini di lakukan pada saat terjadi pasang dan surut.

Kecepatan arus diukur dengan menggunakan layang-layang arus yang dilengkapi tali sepanjang 5 meter. Alat ini dilepaskan di perairan dan dibiarkan hanyut hingga tali tegang/lurus. Selisih waktu pada saat pelepasan alat dan saat tali tegang dihitung sebagai kecepatan dengan menggunakan stopwatch.

Pengukuran kecepatan arus di ukur dengan menggunakan rumus (1):

$\mathrm{V}=\frac{s}{t}$

Keterangan :

$\mathrm{V}=$ Kecepatan arus $(\mathrm{m} / \mathrm{s})$

$\mathrm{S}=\operatorname{Jarak}(\mathrm{m})$

$\mathrm{T}=$ Waktu (s)

Pengukuran derajat keasaman dilakukan dengan menggunakan kertas $\mathrm{pH}$ indikator.

Masukkan botol DO kedalam water dan masukkan ke dalam perairan sesuai dengan kedalaman yang diinginkan untuk mempeoleh air sample,

\section{Analisis Data}

Kelimpahan relative adalah pesentase dari jumlah individu suatu jenis terhadap jumlah seluruh individu yang terdapat di area tertentu dalam suatu komunitas dan dirumuskan sebagai berikut:

Kelimpahan relatif menurut odum (1993) rumuskan sebaga berikut :

$\mathrm{KR}=\frac{n i}{\mathrm{~N}} X 100 \%$

Keterangan:

$\mathrm{KR}=$ Kelimpahan relatif

$n i=$ Jumlah individu spesies $\mathrm{ke}-\mathbf{i}$

$\mathrm{N}=$ Jumlah seluruh individu

Pengolahan analisis hubungan kelimpahan benih lobster menggunakan rumus Sugiyono (2007) sebagai berikut:

$r=\frac{\mathrm{N} \Sigma \mathrm{XY}-(\Sigma \mathrm{X})(\Sigma \mathrm{Y})}{\sqrt{\mathrm{N} \Sigma \mathrm{X}^{2}}-(\Sigma \mathrm{X})^{2}\left(\mathrm{~N} \Sigma \mathrm{Y}^{2}-\left(\Sigma \mathrm{Y}^{2}\right)\right)}$ 
Keterangan :

$\mathrm{r}=$ koefisien korelasi

$\mathrm{X}=$ Variabel yang diukur

$\mathrm{N}=$ Jumlah total sampel

$\mathrm{Y}=$ Variabel yang diukur

Hasil yang diperoleh disesuaikan dengan pedoman interpretasi terhadap koefisien korelasi menurut Sugiyono (2007) disajikan pada Tabel 2.

Tabel 2. Kriteria Koefisien Korelasi

\begin{tabular}{cc}
\hline Interval Koefisen & Tingkat \\
Korelasi & Hubungan \\
\hline $0,00-0,199$ & Sangat rendah \\
$0,20-0,399$ & Rendah \\
$0,40-0,599$ & Sedang \\
$0,60-0,799$ & Kuat \\
$0.80-1,00$ & Sangat Kuat \\
\hline
\end{tabular}

\section{Hasil dan Pembahasan}

Berdasarkan hasil penelitian jenis lobster yang tertangkap di perairan Desa Ranooha Raya yaitu jenis benih lobster mutiara (P.ornatus) dan benih lobster pasir ( $P$. homarus), di mana kedua speies ini termasuk dua dari enam spesies benih lobster endemik di perairan Indonesia. Hal ini sesuai dengan pernyataan Caperleman (2015), bahwa terdapat enam jenis lobster di perairan Indonesia, enam jenis tersebut merupakan jenis yang menghuni perairan tropika, yaitu lobster pasir $(P$. homarus), lobster batu (P.penicillatus), lobster batik(P. longipes), lobster mutiara (P.ornatus).

Presentase kelimpahan relatif jenis benih lobster (panulirus spp.) berdasarkan pengamatan mempunyai nilai yang bervariasi dengan kisaran masing masing antara minggu 13. Persentase kelimpahan tertinggi yaitu pada minggu pertama dan minggu ketiga jenis benih lobster mutiara ( $P$. ornatus) yaitu $67.10-69.85 \%$ sedangkan persentase kelimpahan jenis benih lobster pasir ( $P$. homarus) tertinggi yaitu pada minggu kedua yaitu 44.44-44.57\% (Tabel.4.). Hal ini di karenakan pengambilan sampel disetiap periode terdapat cauaca-cuaca yang kurang mendukung seperti hujan lebat yang menyebabkan banjir dan terjadi arus yang berlawanan, sehingga benih lobster pada stasiun tersebut akan perpindah tempat ke alat tangkap lainnya maupun ke lokasi asalnya, sehingga kelimpahan disetiap minggunya bervariasi. Setya et al., (2014), yang menyatakan kecepatan arus akan berperan dalam proses migrasi dan penyebaran larva sebagai organisme yang pasif sehingga pergerakannya sangat ditentukan oleh arus.

Hasil penelitian kelimpahan benih lobster (Panulirus spp.) yang mendominasi perairan Ranooha Raya yaitu pada stasiun I yang terdiri atas jenis lobster mutiara berkisar antara 522 ind. $/ \mathrm{m}^{2}$ dengan jumlah jenis lobster pasir 398 ind. $/ \mathrm{m}^{2}$. Hal ini didukung oleh karakteristik substrat dasar berpasir, yang disukai oleh benih lobster untuk melakukan perlidungan dari predator maupun melakukan pergantian kulit serta pengaruh factor fisika-kimia perairan, sehingga kelimpahan lebih melimpah dibandingkan dengan stasiun II dan III. Hal ini sesuai pernyataan Iksan et al., (2019), yang menyatakan selama masa pertumbuhan lobster terdapat beberapa faktor yang mempengaruhi pertumbuhan dan kelimpahan lobster diantaranya adalah lingkungan, factor individu faktor ekologi perairan dan beberapa faktor penting lainnya.

Kondisi perairan Desa Ranooha Raya masih mendukung untuk kehidupan, pertumbuhan dan perkembangan benih lobster (Panulirus spp.). Variabel suhu, salinitas, kecerahan, kedalaman, kecepatan arus, $\mathrm{pH}$, dan DO (oksigen terlarut). Dimana parameter ini sangat mempengaruhi keberadaan, pertumbuhan, reproduksi, dan migrasi benih lobster di suatu perairan. Thangaraja dan Radhakrishnan (2012), bahwa parameter lingkungan merupakan faktor pembatas dari distribusi setiap spesies lobster. Setiap spesies memiliki habitat dengan karakteristik yang spesifik sesui kebutuhannya terkait ketersediaan makanan, tempat berlindung, dan reproduksinya dapat dilihat pada table 7 dan 8 .

Hasil analisis hubungan kelimpahan benih lobster (Panulirus sp.) berdasarkan karakteristik oseanografi minggu 1-3 pada setiap stasiun penelitian. Suhu juga factor penting yang sangat mendukung kehidupan biota dalam perairan seperti benih lobster. Hasil penelitian diperoleh kisaran suhu perairan yaitu $29-30^{\circ} \mathrm{C}$, kisaran suhu perairan dengan tingkat hubungan yang kuat dengan nilai 0.78 kisaran suhu tersebut yang memiliki tingkat kelimpahan yang masih normal untuk pertumbuhan benih lobster mutiara dan pasir dan mampu mendukung kehidupan organisme lainnya. Ikhsan et al., (2019), yang menyatakan Lobster (Panulirus spp.) umumnya ditemukan pada lingkungan perairan dari permukaan sampai pada kedalaman beberapa meter, terutama di perairan hangat. Hasil pengukuran kualitas air menunjukkan adanya 
nilai yang berfluktuasi pada beberapa parameter kualitas air yang diukur seperti suhu $29-31^{\circ} \mathrm{C}$, tinggi rendahnya nilai fluktuasi kualitas air diduga dipengaruhi oleh beberapa faktor seperti kondisi cahaya matahari, yang diperoleh diindikasikan masih dalam kondisi yang baik untuk kelangsungan budidaya.

Salinitas merupakan salah satu parameter lingkungan yang mempengaruhi proses biologi dan secara tidak langsung akan mempengaruhi kehidupan organisme yaitu mempengaruhi laju pertumbuhan, jumlah makanan dan daya kelangsungan hidup. Hasil penelitian diperoleh kisaran salinitas perairan yaitu 29-34 ppt, kisaran salinitas perairan dengan tingkat hubungan sedang dengan nilai 0.42 , kisaran salinitas tersebut mampu mendukung kehidupan benih lobster dari tingkat keasinan atau kadar garam terlarut dalam air masih baik. Hal ini sesuai dengan penelitian La suriadi et al., (2017), yang menyatakan kisaran salinitas masih dalam keadaan optimum yaitu 33-35 ppt menunjukkan masih menunjang kehidupan organisme lobster.

Kecerahan perairan adalah kemampuan cahaya menembus lapisan kedalaman tertentu sehingga kecerahan menjadi faktor penting bagi proses fotosintesis dan produksi primer pada perairan, sehingga hal ini sangat dipengaruhi oleh kekeruhan. kisaran kecerahan perairan yaitu 5893\%, masih ada penetrasi cahaya matahari yang masuk ke dalam air dan tingkat kekeruhan yang kurang sehingga pada daerah tersebut mengalami tingkat kelimpahan yang tinggi. Hal ini sesuai dengan pernyataan Yulika (2012), yang menyatakan bahwa kecerahan perairan adalah suatu kondisi yang menunjukkan kemampuan cahaya untuk menembus lapisan air pada kedalaman tertentu, pada perairan alami kecerahan sangat penting karena erat kaitannya dengan aktifitas fotosintesa. Kecerahan merupakan faktor penting bagi proses fotosintesa dan produksi primer dalam suatu perairan.

Tabel 3. Hasil Pengkuran Parameter Kualitas Perairan per Minggu

\begin{tabular}{|c|c|c|c|c|}
\hline \multirow{2}{*}{ No. } & \multirow{2}{*}{ Parameter } & \multicolumn{3}{|c|}{ Stasiun } \\
\hline & & I & II & III \\
\hline \multirow[t]{4}{*}{1.} & Suhu $\left({ }^{\circ} \mathrm{C}\right)$ & 30 & 29 & 30 \\
\hline & & 29 & 29 & 30 \\
\hline & & 29 & 30 & 30 \\
\hline & Rata-rata & 29.33 & 29.33 & 30 \\
\hline \multirow[t]{4}{*}{2.} & Salinitas (ppt) & 35 & 30 & 35 \\
\hline & & 34 & 29 & 35 \\
\hline & & 29 & 29 & 34 \\
\hline & Rata-rata & 32.66 & 29.33 & 34.66 \\
\hline \multirow[t]{4}{*}{3.} & Kecerahan (m) & 8 & 7.5 & 5 \\
\hline & & 8 & 7.5 & 5 \\
\hline & & 7 & 4 & 3.5 \\
\hline & Rata-rata & 7.6 & 6.3 & 4.5 \\
\hline \multirow[t]{4}{*}{4.} & Kedalaman (m) & 11 & 8 & 8 \\
\hline & & 11 & 8 & 8 \\
\hline & & 10 & 6 & 6 \\
\hline & Rata-rata & 10.66 & 7.33 & 7.33 \\
\hline \multirow[t]{4}{*}{5.} & Kecepatan Arus (m/s) & 0.09 & 0.08 & 0.09 \\
\hline & & 0.09 & 0.08 & 0.09 \\
\hline & & 0.09 & 0.08 & 0.010 \\
\hline & Rata-rata & 0.09 & 0.08 & 0.063 \\
\hline \multirow[t]{4}{*}{6.} & $\mathrm{Ph}$ & 8 & 8 & 7 \\
\hline & & 8 & 8 & 7 \\
\hline & & 8 & 7 & 7 \\
\hline & Rata-rata & 8 & 7.6 & 7 \\
\hline \multirow[t]{4}{*}{7.} & $\mathrm{DO}(\mathrm{mg} / \mathrm{L})$ & 5.2 & 5.3 & 5.7 \\
\hline & & 5.7 & 5.1 & 5.8 \\
\hline & & 5.1 & 5.3 & 5.7 \\
\hline & Rata-rata & 5.3 & 5.23 & 5.73 \\
\hline
\end{tabular}


Tabel 4. Hasil Analisis Kelimpahan Relatif Benih Lobster (Panulirus spp.)

\begin{tabular}{|c|c|c|c|c|c|c|c|}
\hline \multirow{3}{*}{ Stasiun } & \multirow{3}{*}{ Jenis Species } & \multicolumn{6}{|c|}{ KR (\%) } \\
\hline & & \multicolumn{2}{|c|}{ Minggu I } & \multicolumn{2}{|c|}{ Minggu II } & \multicolumn{2}{|c|}{ Minggu III } \\
\hline & & $\mathbf{n}$ & $\%$ & $\mathrm{n}$ & $\%$ & $\mathrm{n}$ & $\%$ \\
\hline \multirow[t]{2}{*}{ I } & $\begin{array}{l}\text { Benih lobster mutiara } \\
\text { (P. ornatus) }\end{array}$ & 57 & 62.63 & 194 & 55.42 & 271 & 56.57 \\
\hline & $\begin{array}{l}\text { Benih lobster pasir ( } P \text {. } \\
\text { homarus) }\end{array}$ & 34 & 37.36 & 156 & 44.57 & 208 & 43.42 \\
\hline \multirow[t]{2}{*}{ II } & $\begin{array}{l}\text { Benih lobster mutiara } \\
\text { (P. ornatus) }\end{array}$ & 15 & 55.55 & 52 & 59.34 & 88 & 62.41 \\
\hline & $\begin{array}{l}\text { Benih lobster pasir ( } P \text {. } \\
\text { homarus) }\end{array}$ & 12 & 44.44 & 56 & 40.65 & 53 & 37.58 \\
\hline \multirow[t]{2}{*}{ III } & $\begin{array}{l}\text { Benih lobster mutiara } \\
\text { (P. ornatus) }\end{array}$ & 51 & 67.10 & 162 & 59.34 & 248 & 69.85 \\
\hline & homarus) & 25 & 32.89 & 111 & 40.65 & 107 & 30.14 \\
\hline
\end{tabular}

Tabel 5. Hasil Analisis Jenis dan Jumlah Benih Lobster (Panulirus spp.)

\begin{tabular}{clcccc}
\hline No. & \multicolumn{1}{c}{ Jenis Spesies } & Stasiun I & Stasiun II & Stasiun III & Jumlah \\
\hline 1 & $\begin{array}{l}\text { Benih lobster mutiara } \\
\text { (P. } \text { ornatus) }\end{array}$ & 522 & 155 & 456 & 1,133 \\
\hline 2 & $\begin{array}{l}\text { Benih lobster pasir } \\
\text { (P. homarus) }\end{array}$ & 398 & 121 & 243 & 762 \\
\hline \multicolumn{1}{c}{ Jumlah } & $\mathbf{9 2 0}$ & $\mathbf{2 7 6}$ & $\mathbf{6 9 9}$ & $\mathbf{1 , 8 9 5}$ \\
\hline
\end{tabular}

Tabel 6. Hasil Analisis Korelasi Hubungan Kelimpahan Benih Lobster Mutiara (P. ornatus) Berdasarkan Karakteristik Oseanografi.

\begin{tabular}{lccccccc}
\hline Jenis Species & KR & $\begin{array}{c}\text { Suhu } \\
\left({ }^{\circ} \mathrm{C}\right)\end{array}$ & $\begin{array}{c}\text { Salinitas } \\
(\mathrm{ppt})\end{array}$ & $\begin{array}{c}\text { Kecerahan } \\
(\%)\end{array}$ & $\begin{array}{c}\text { Kecepatan Arus } \\
(\mathrm{m} / \mathrm{det})\end{array}$ & $\mathrm{pH}$ & $\begin{array}{c}\mathrm{DO} \\
(\mathrm{mg} / \mathrm{l})\end{array}$ \\
\hline & 62.63 & 30 & 35 & 72 & 0.09 & 8 & 5.2 \\
& 55.42 & 29 & 34 & 72 & 0.09 & 8 & 5.7 \\
& 56.57 & 29 & 29 & 70 & 0.09 & 8 & 5.1 \\
\cline { 2 - 9 } Lobster Mutiara & 55.55 & 29 & 30 & 93 & 0.08 & 8 & 5.3 \\
P. ornatus & 59.34 & 29 & 29 & 93 & 0.08 & 8 & 5.1 \\
& 62.41 & 30 & 29 & 66 & 0.08 & 7 & 5.3 \\
& 67.1 & 30 & 35 & 62 & 0.09 & 7 & 5.7 \\
& 59.34 & 30 & 35 & 62 & 0.09 & 7 & 5.8 \\
& 69.85 & 30 & 34 & 58 & 0.09 & 7 & 5.7 \\
\hline Korelasi (R) & & 0.783 & 0.429 & -0.605 & 0.267 & -0.703 & 0.349 \\
Hubungan & & Kuat & Sedang & Kuat & Rendah & Kuat & Rendah \\
\hline
\end{tabular}


Tabel 7. Hasil Analisis Korelasi Hubungan Kelimpahan Benih Lobster Pasir (P. Homarus) Berdasarkan Karakteristik Oseanografi.

\begin{tabular}{lccccccc}
\hline Jenis Species & KR & $\begin{array}{c}\text { Suhu } \\
{ }^{\circ} \mathrm{C}\end{array}$ & $\begin{array}{c}\text { Salinitas } \\
(\mathrm{ppt})\end{array}$ & $\begin{array}{c}\text { Kecerahan } \\
\%\end{array}$ & $\begin{array}{c}\text { Kecepatan Arus } \\
(\mathrm{m} / \mathrm{det})\end{array}$ & $\mathrm{pH}$ & $\begin{array}{c}\text { DO } \\
(\mathrm{mg} / \mathrm{L})\end{array}$ \\
\hline & 37.36 & 30 & 35 & 72 & 0.09 & 8 & 5.2 \\
& 44.57 & 29 & 34 & 72 & 0.09 & 8 & 5.7 \\
& 43.42 & 29 & 29 & 70 & 0.09 & 8 & 5.1 \\
\cline { 2 - 8 } Lobster Pasir & 44.44 & 29 & 30 & 93 & 0.08 & 8 & 5.3 \\
P. homarus & 40.65 & 29 & 29 & 93 & 0.08 & 8 & 5.1 \\
& 37.58 & 30 & 29 & 66 & 0.08 & 7 & 5.3 \\
\cline { 2 - 8 } & 32.89 & 30 & 35 & 62 & 0.09 & 7 & 5.7 \\
& 40.65 & 30 & 35 & 62 & 0.09 & 7 & 5.8 \\
& 30.14 & 30 & 34 & 58 & 0.09 & 7 & 5.7 \\
\hline Korelasi (R) & & -0.783 & -0.429 & 0.605 & -0.267 & 0.703 & -0.349 \\
Hubungan & & Kuat & Sedang & Kuat & Rendah & Kuat & Rendah \\
\hline
\end{tabular}

Kecepatan arus merupakan faktor yang sangat mempengaruhi keberadaan benih lobster (Panulirus sp.) di daerah sekitar pesisir karena sifatnya yang masih plantonik sehingga mudah terbawa oleh arus. Hasil penelitian dieroleh kisaran kecepatan arus yaitu $0.08-0.09 \mathrm{~m} / \mathrm{det}$, hal ini masih tergolong arus yang tidak terlalu kuat, bila kecepatan arus sangat kuat benih lobster pada stasiun tersebut akan perpindah tempat ke alat tangkap lainnya yang mempunyai kecepatan arus yang sedang sehingga benih lobster tersebut bisa bersembunyi di sela-sela alat tangkap masyarakat. Hal ini sesuai dengan pernyataan Setya et al., (2014), yang menyatakan kecepatan arus akan berperan dalam proses migrasi dan penyebaran yang bersifat larva atau planktonik sebagai organisme yang pasif sehingga pergerakannya sangat ditentukan oleh arus.

Hasil pengkuran $\mathrm{pH}$ secara in situ setiap stasiun pengamatan terdapat berbedaan yakni nilai $\mathrm{pH}$ 7-8 memenuhi baku mutu air laut untuk kelangsungan hidup biota laut dan memiliki tingkat hubungan kuat dengan nilai 0.77 , terhadap kelimpahan benih lobster dan masih dapat hidup ideal dan berasosiasi dalam kisaran $\mathrm{pH}$ perairan tersebut. Hal ini sesuai dengan pernyataan Megawati et al., (2014) bahwa variasi nilai $\mathrm{pH}$ perairan sangat memenuhi biota disuatu perairan, $\mathrm{pH}$ air normal adalah 7,2-8,1. Dengan kisaran $\mathrm{pH}$ air yang demikian, dikatakan masih layak untuk semua kebutuhan hidup organism perairan.

Berdasarkan hasil analisis nilai DO (Oksigen terlarut) yang didapatkan berada pada kisaran 5.3-5.73 $\mathrm{mg} / \mathrm{l}$, hal ini perairan tersebut masih dalam keadaan normal belum tercemar oleh senyawa beracun sehingga masih bisa di pergunakan dalam budidaya perikanan. Hal ini sesuai $\mathrm{Hal}$ ini sesuai dengan penelitian Salim et al., (2017), yang menyatakan bahwa Do berkisar antara 4.8 $\mathrm{mg} / \mathrm{L}$ sampai dengan 7.5 jika mengacu pada Kepmen LH No. 51 Tahun 2004 maka nilai DO di perairan ini cukup baik atau memenuhi baku mutu. Hal ini menunjukkan bahwa pengaruh perairan sekitarnya terutama gelombang sangat berpengaruh sebagai oksigenasi air laut.

\section{Kesimpulan}

1. Parameter oseanografi pada lokasi penelitian di perairan Desa Ranooha Raya parameter: suhu berkisar $29-30{ }^{\circ} \mathrm{C}$, salinitas 29-34 ppt, kecerahan 58-93\%, kecepatan arus 0.08-0.09 m/det, $\mathrm{pH}$ 7-8 dan DO 5.3$5.73 \mathrm{mg} / \mathrm{L}$.

2. Kelimpahan pada lokasi penelitian untuk jenis lobster mutiara (Panulirus ornatus) berkisar 55.42-69.85\% dan untuk benih lobster pasir (Panulirus homarus) berkisar $30.15-44.58 \%$.

3. Terdapat hubungan yang kuat antara kelimpahan benih lobster berdasarkan karakteristik oseanografi perairan seperti. Suhu, salinitas, kecerahan, dan $\mathrm{pH}$. Dimana Suhu dan $\mathrm{pH}$ merupakan factor yang sangat mempengaruhi keberadaan benih lobster (Panulirus spp.) di perairan. 


\section{Ucapan Terimakasih}

Penulis mengucapkan banyak terima kasih kepada pembimbing dan penguji yang telah memberikan saran dan bimbingan serta teman-teman yang telah membantu baik dalam pengambilan data sampai penyusunan skripsi ini, sehingga dapat terselesaikan dengan baik.

\section{Daftar Pustaka}

Capeleman. 2015. Sountheast Asia Crustacean and Mollusca Identinfication. (Online). Tersedia di Laman:

http://capeleman.blogspot.com/p/southe ast-asia-crustacean-and-mollusca.html. Diakses pada Tanggal 15 April 2015.

Erlania, Radiarta, N. dan Sugama, K. 2014. Dinamika Kelimpahan Benih Lobster (Panulirus spp.) di perairan Teluk Gerupuk, Nusa Tenggara Barat: Tantangan Pengembangan Teknologi Budidaya Lobster. Jurnal Ris. Akuakultur Vol. 9 (3): 475-489.

Hamuna B., Tanjung H.R, R.,Suwito.,Maury K.H., Alianto. 2018. Kajian Kualitas Air Laut dan Indeks Pencemaran Berdasarkan Parameter Fisika-Kimia Di Perairan Distrik Depapre, Jayapura. Jurnal Ilmu Lingkungan. Vol. 16(1): Hal 35-43.

Hasriyanti., Syarif, E., Madatuang. 2015. Analisis Karakteristik Kedalaman Perairan, Arus dan Gelombang di Pulau Dutungan Kabupaten Barru. Jurnal Scientific Pinisi. Vol.1(1). Hal 44-54.

Ikhsan, M., Yusnaini., Idris, M. 2019. Pengaruh Jenis Pakan Segar Terhadap Pertumbuhan Biomassa Calon Indukan Lobster Batik (Panulirus longipes) yang Dipelihara pada Dasar Perairan. Media Akuatik. Vol. 4(1). Hal. 25-33

La suriadi., Yusnaini., Agus, K. 2017.Pengaruh Jenis Pakan Segar Terhadap Pertumbuhan Biomassa Calon Induk Lobster Batik (Panulirus longipes). Media Akuatik. Vol. 2(2). Hal. 360-367.

Megawati, C., Yusuf, M., dan Maslukah, L. 2014. Sebaran Kualitas Perairan Ditinjau Dari Zat Hara, Oksigen Terlarut dab $\mathrm{pH}$ di Perairan Selatan Bali Bagian Selatan. Jurnal Oseanografi, Vol. 3(2): 142-150.
Nugraini, D, P., Suprapto, D., Wahyu, P, P. 2014. Karakteristik Fisika Kimia Perairan Habitat Bivalvia di Sungai Wiso Jepara. Journal Of Maquares. Vol. 3(4). Hal 141-146.

Nugraini, D, P., Suprapto, D., Wahyu, P, P. 2014. Karakteristik Fisika Kimia Perairan Habitat Bivalvia di Sungai Wiso Jepara. Journal of Maquares. Vol. 3(4). Hal 141-146.

Pratiwi, R. 2013. Lobster Komersial (Panulirus spp.). Jurnal Oseana, Vol. 38 (2): 55-68.

Puspitasari R, \& Natsir M,S. 2016. Kualitas Lingkungan Untuk Menunjang Budi Daya Biota Laut di Perairan Lombok Barat. Lembaga Ilmu Pengetahuan Indonesia (LIPI).

Salim, D., Yuliyanto., Baharuddin. 2017. Karakteristik Parameter Oseanografi Fisika-Kimia Perairan Pulau Kerumputan Kabupaten Kotabaru Kalimantan Selatan. Jurnal Enggano. Vol. (2). Hal. 218-228.

Setya, M, A., Hendrarto, B., Wahyu, P, P. 2014. Distribusi Kelimpahan Fitoplankton dan Klorofil-A di Teluk Sekumbu Kabupaten Jepara Hubungannya dengan Kandungan Nitrat dan Fosfat di Perairan. Vol. 3(2). Hal. 138-147.

Simajuntak M. 2007. Oksigen Terlarut dan Oksigen Terlarut dan Oksigen Apparent Oxygen Utilization Apparent Oxygen Utilization di Perairan Teluk Klabat, Pulau Bangka. Ilmu Kelautan UNDIP. Vol. 12(2): Hal 59-66.

Thangaraja, R. dan Radhakrishnan, E.V. 2012. Fishery and ecology of the spiny lobster Panulirus homarus (Linnaeus, 1758) at Khadiyapatanam in the southwest coast of India. J. Mar. Biol. Ass. India, 54(2), 69-79.

WWF Indonesia. 2015. Perikanan Lobster Laut, Panduan Penangkaan dan Penangkapan. Gedung Graha Simatupang. Tower 2 unit C, Lantai 7 Jalan Letjen TB Simatupang Kav. 38 Jakarta Selatan 12540. 